\title{
The Need for the Factor Hermeticism in the Renaissance Thinking
}

\author{
Shakhnoza Madaeva, Khurshid Toshov
}

\begin{abstract}
Abstarct: It is well known that after the collapse of the Soviet Union, the interest in studying the culture and philosophy of the Renaissance in the post-Soviet area grew even more. This article discusses the controversial aspects of the study of the Renessas era and shows the need for a hermetic tradition in understanding it. This is because humanistic ideas of the Renaissance display many elements of esoteric traditions. With the collapse of the ideological monopoly of the former Soviet Union, a pluralistic principle from the paradigmatic point of view in various fields of science, particularly in the social and humanitarian field, began to dominate. In particular, the study of the Renaissance focused on the influence of various esoteric traditions. Our aim is to identify the causes of the same relationship by analyzing two overlapping views on the tradition of hermeticism in the Renaissance. At the same time, special attention is paid to the peculiarities of hermetic ideas as a paradigm.
\end{abstract}

Keywords: Hermeticism, Hermes, Poimander, God=Mind $=$ Father=Light, Son=Word, Um=Demiurge, Ficino, Asclepius, God-man, paganism, Tot, Christianity.

\section{INTRODUCTION}

When we talk about the history of philosophy in the CIS countries, we see a group of scientists and philosophers exploring the history of philosophy in the paradigm of the former Soviet Union. According to this paradigm, philosophy has traditionally been regarded as a linear process of evolution, starting with the ancient Greek naturalists until the emergence of certain philosophical teachings. This ideal model of philosophy is defined by the existence of concrete elements: to be more precise, ideals closer to ideal atheism or dialectical materialism.

If the doctrines that met this standard were considered progressive, their inconsistencies were too brief or were excluded as research objects. According to this approach, philosophical doctrines of the religious-irrational nature have been placed in the background as much as possible, and philosophers who have been engaged in philosophical thinking have never been included in the history of philosophy or have been given very brief information. Except for medieval religious philosophy, which has been discussed in more detail. However, this part of the history of philosophy has been treated negatively, mainly focusing on the criticism of scholastics. Thus, the ideas of the religiousirrational spirit of philosophical history other than the medieval period have been virtually ignored. To be sure, it is enough to look at the contents of any book on philosophy that dominates this approach.

In recent years, the situation has changed dramatically in the history of philosophy in the CIS countries, and religious schools and currents have become the subject of serious research. The life and views of thinkers based on many religious and mystical doctrines, such as Berdyaev, Solovev, Tolstoy, Teyyar de Sharden, Mariten, Rumi, Yassawi, Nakshbandi, Nasafi, Hallaj, Kubro, Gijduvani also serve as philosophical and historical studies. However, from the point of view of history of philosophy such research is not enough.

The one-dimensional nature of the methodology used in this philosophy's historical paradigm has manifested itself in the post-Soviet space, with its theoretical and practical implications. Such methodological limitations, first of all, have led to a biased, incomplete, and most importantly, onesided interpretation of the history of philosophy, without envisioning a holistic picture of the development of philosophical thinking.

In addition, it has led to the exclusion of certain doctrines and currents of esoteric, irrational, religious and mystical spirit, either as a model or as a structural element in the development of philosophical thought. As a result, the impact of such doctrines on the development of philosophical thought as a whole and the development of philosophical thought has led to the emergence of unbiased approaches to the formation of particular historical or cultural events.

For example, the problem of herotism in the formation of modern science as a social institution, in particular, was the fact that the decisive factor of hermeticism became known in western science in the second half of the 19th century.

The limited nature of this methodology, in practical terms, has led to a lack of information about the spiritual gaps in the social consciousness, namely, esoteric views. As a consequence, there is a dual attitude between schools and currents in an irrational spirit, which causes social and ideological contradictions in society, and thus mutually ignore each other.

Revised Manuscript Received on October 15, 2019.

Shakhnoza Madaeva, Professor of the National University of Uzbekistan named after Mirzo Ulugbek, Uzbekistan.(Email: sh.madaeva@nuu.uz)

Khurshid Toshov, Senior Lecturer of the National University of Uzbekistan named after Mirzo Ulugbek, Uzbekistan.(Email: h.toshev@nuu.uz). 
In the first, the positive aspects of the role of esoteric groups and streams in the social and spiritual sphere are exaggerated, and in the second, the negative aspects of this function are exaggerated. Such contradictions are directly related to the low awareness of the general population, even the educated.

\section{REVIEW OF THE LITERATURE ON THE TOPIC}

In the history of philosophy, the methodological importance of hermeticism in the understanding of the such studies, the authors' position is illuminated from the point of view of time and space. These include F. Zelinsky [1], A. Stranden [2], F. Yeats [3], J. Maye [4], A. Festujer [5], V. Scott [6], S. Panin [7] Monographs, brochures and articles by N.Shaburov [8] and to some extent have been studied the notion of the period of awareness and the hermetic factor in it.

\section{RESEARCH METHODOLOGY}

In the course of the research, general and philosophical methods were used, such as historicity and objectivity, abstractions to concrete, analysis and synthesis, deduction, comparative analysis, fremenging.

\section{ANALYSIS AND RESULTS}

This pluralistic ideology of freedom is also explained by the fact that the translation of texts on the traditions of hermeticism into Russian and the emergence of philosophical historical studies related to the study of the same ideas in post-Soviet territory. The influence of hermeticism on the culture and thinking of the period was studied in philosophical historical studies on the study of the Renaissance in the post-Soviet area.

In particular, the role of hermetic ideas in the development of Italian renaissance has been thoroughly analyzed, and the question of the influence of hermetic ideas on the development of English renaissance is left unnoticed by researchers. Certainly, it is necessary to agree with F. Yeats's opinion that it is impossible to understand the Renaissance without exploring the ideas expressed in the texts of the hermetic source, the hermetic corpus.

Especially when one considers the views of T.Mor, the preacher of the doctrine of humanism in the spirit of humanism, a friend and friend of Erasmus of Rotterdam, J. Calet (1466-1519), it is appropriate. Visiting Italy in the 90s of the 15th century, Colette Marsilio Fichino and Giovanni Pico della Mirandola became acquainted with the concept of "common religion" and became a supporter of it.

In this concept, all elements of theological tradition from antiquity to Christianity are combined into one doctrine on a consistent basis. The general religion of this scientific spirit places great emphasis on Plato's ideas, and his teachings are regarded as the science of theology. Under the influence of M. Ficino, Colette is interested in Plato and the ideas of neoplatonism, including Erasmus, who writes: Renaissance and its understanding is thoroughly studied. In

However, it is striking that J.Collet's critical view of pagan philosophy is quite critical. This is illustrated by the following excerpt from Colette's lecture at the University of Oxford: "We must feed on Jesus alone. The water that Moses brought out should be eaten at the table of Jesus and the wine-writings, as well as at the table of the Bible. Other tableware, especially the pantheon of writers, has no taste of Jesus, only the devil. A Christian, who prefers to be a guest of God rather than a guest of the devil, should not sit at the table with which I have spoken.

Where man is nourished, he grows on it. If we seek pagan wisdom, we will lose the true laws of God. "[11] Much of the passage cites Christian doctrine, such as hermeticism and platonism, is inconsistent with the general concept of religion and is contrary to $\mathrm{J}$. Colette's acceptance of this concept and the glorification of Plato's ideas. More precisely, there seems to be a contradiction between $\mathrm{J}$. Colet's views on paganism [12]. The above excerpt is a critique of the humanist culture of the Renaissance

The opinion that J.K.'s belong to the Crete can be questioned. There are three different approaches to philosophical historical research: the first approach does not focus on the above passage, and the second one deals with the argument that J. Colette is conservative and antihumanist. In the third approach, the above passage is regarded as an unresolved controversial aspect of J. Colette's worldview [14]. Hermetism can serve as an important ideological and methodological basis for the solution of this problem.

The ideas of hermeticism, which form the core of the Renaissance culture, synthesized both Greek and Roman philosophical teachings such as gnosticism, stoicism, neoplatonism, and Christianity and magic. In $1463 \mathrm{M}$. Fichino translated and published the treatises of hermeticism carried out by many Byzantine settlers to Western Europe. M. Fichino translated hermetic treatises earlier than Plato.

Following the hermetic corpus, there will be a series of translations of the "Anthem of the Orpheus" and the Zoroastrian works that are considered to be the authors of the Chaldeans. Hermès Trismegist, Orpheus, Zoroastrianism believes that M. Fichino is correct. In the genealogy of the authors of the theological works of the Renaissance, the writers of ancient divine philosophy, who were either Hermes's successors or contemporaries of Orpheus and Zoroastrians, were considered to be ancient prophets, whose teachings were far superior to the religion of Moses and Jesus, as well as Plato.

M.Fichino considers these texts to be ancient monuments, as evidenced by his unprofessional approach as a philologist. Only a year after the translation of the Hermetic Corps, he began to translate the works of Plato and neoplatonists.

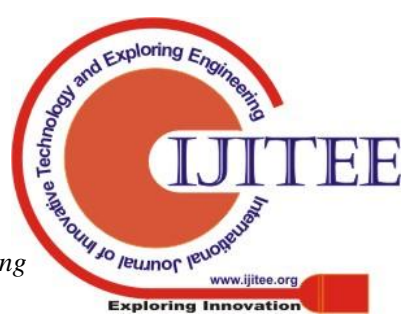


Due to her interest in hermetic ideas, M. Fichino began to study natural magic. Natural magic did not contradict the Christian ideas of M. Fichino's interpretation. As D. Walker and F. Yeates correctly point out, the fundamental magic of M. Fichino's theory lies in the idea of the universal revival of everything in the doctrine of neoplatonism. According to him, "Spiritus mundi" - a subtle pneumatic substance spread throughout the world, encompassing the human body and the cosmos and serves as a means for the stars to influence people.

M.Fichino was involved in a specific natural therapy, using the various rock, plants, shell shells, instrumental music, and various stars and planets, orchestrated by the heavenly bodies to invoke the spirits of the heavenly bodies and bring them into the human body and spirit. In the "Calling Life From Heavens" tract, M. Fichino describes the process of controlling the flow of the spirit of the universe through talismans that conserve the energy of stars [16]. Fichino did not point out that the magical medical therapy he was dealing with was incompatible with Christianity.

Giovanni Pico della Mirandolla, another author of the Plato Academy of Florence, explores this in more detail in his work. In literature and research on the history of philosophy in the post-Soviet area, only Pico's essay, "The Discourse on the Dignity of Man," has been studied [17]. In this work, the person is glorified and is known as the "Great Miracle". This work can be considered as a manifestation of humanism. In it, man is glorified as a divine being, not only on earth or in space, but also because of his creative activity. The idea of glorifying humanity in the works of humanist thinkers is in close agreement with the human image depicted in the Asklepian diology of the hermetic corpus.

In Asklepy, he is regarded as a great, miraculous creature worthy of worship. He becomes as divine as he is. He knows that he has a common affinity with the devils. He despises his divine part and despises the part of his human nature [19]. Apparently, Pico does not glorify man-made creatures, but rather writes about magical creation, which by its origin is associated with the demonic spirits of stars.

It is the magician who imitates God by calling life out of the celestial bodies and bringing it into the lower world [20].

There is a striking contrast between the notions of human nature in Christianity on the one hand, the idea of honoring human beings, as suggested by F. Petrarka and the anthropocentricism of the Renaissance humanists on the other. The idea expressed in the above excerpt from Pico's speeches has fueled interest in the occult activities of the Renaissance thinkers, such as the natural magic and the kabbalah. At the same time, it is necessary to remember the main purpose of this speech, written in 1486.

M. Pico's goal was to synthesize all knowledge. To this end, he has compiled over 900 theses, synthesizing elements of occultism, philosophy and theology. He also referred to a number of elements of esoteric movements such as ancient philosophical schools and hermetic texts, astrological teachings of the Chaldeans, Jewish kabbalas, and orthodox hymns. Importantly, these 900 theses provide the methodological framework for the ideas of hermetic, which are syncretically present elements of the above-mentioned fields. Thesis reveals the despotism of Roman theology. The book, "On the Value of Human Dignity," also draws attention to this despotism, but one of Pico's theses is not in conflict with the other. These theses together provide a fuller understanding of Christianity. The seventh magical conclusion in this work is a terror to Christian intellectuals who lived during the Renaissance. It states, "No other science can convince us that the divinity of Jesus is divine."

In his research on the history of Renaissance magic, his talk on the value of human dignity, Ficino was considered a liberation charter of the humanistic magical tradition of the Renaissance era, enhanced by Pico [22]. The magic offered by Pico consists of two parts. The first part consists of natural magic in the spirit of neoplatonism, founded by $\mathrm{M}$. Fichino, and the second part is based on numbers and the corresponding cabbage, based on the Jewish alphabet. More precisely, M. Pico enriches Fichino's natural magic with cabbage. M. Pico attempts to prove Christianity through this synthesis performed by him.

Thus, the emergence of the ideas of hermeticism as a paradigm of transition during the Renaissance led them to influence the ideas of various Renaissance thinkers. As a result of medieval argumentative research, a dual but compelling conclusion about hermeticism has emerged. That is to say, early medieval thinkers regarded hermeticism as the oldest doctrine of Christianity. But while Lactanti and Cyril Alexandrsky consider Hermes as a follower of Christian doctrine, Augustus considers Hermes an antiquity and considers him a prophet of Christianity, opposed to the devil's Christianity.

M. Ficino and M. Pico are at their disposal. L. Lactantsi and Cyril Alexandrskii formulate the concept of a common religion or synthetic science, based on the ideas of hermeticism, enriched them with kabbalah and many other elements. However, the two conflicting conclusions about the ideas of hermeticism reflected in the early medieval argumentative studies of J. Colet's work leave a deep impression. The ideological inconsistency reflected in the above passage from J. Colette's speech at Oxford is the consequence of the double-mindedness of hermeticism in the same argumentative research. To be more precise, see the struggle between Christian and hermetic ideas put forward by A. Augustine in the tradition of coincidence of Christian and hermetic ideas initiated by L. Lactantsi and Cyril Alexandrsky in the Colette worldview. 
In general, Christian humanism during the Renaissance did not ideologically need the ancient pagan theology. One Erasmus biographer from Rotterdam writes that he was furious when he approached the thinker with the great epithet Thermaximus - Triple. It appears that Erasmus did not like to be considered a hermetic thinker. [23]

Researchers argue that Erasmus did not address the phonetic theology of M. Fichino and M. Pico, and may therefore have been skeptical of the ideas expressed in hermetic texts. Thus, Christian humanists such as J. Colet and Erasmus did not accept A. Augustus' position that the texts of hermeticism were an ancient theological source.

More precisely, they were unable to adopt this concept because of their religious beliefs, despite the hermetic texts and the great interest in the synthetic religion or science proposed by M. Fichino and M. Pico. Research in the study of Renaissance humanism in the history of philosophy emphasizes the following reasons for this phenomenon:

First, the contradictions in the polemical passage from J. Colette's lecture at Oxford above may be a consequence of the influence of M. Pico's thesis on quoting Judaism, Islam, Iran, and Chaldeans. After this speech of M. Pico was published in 1496, J. Colette became acquainted with him. In this work, Colette sees the synthesis of the philosophies of Hermes, Orpheus, Zoroastrianism and the magic of numbers, rather than the ideas of Aristotle, Plato, and neoplatonism, which form the basis of Christian scholasticism.

Speaking of the beliefs of these pagan philosophers, he wrote that "their minds were turning to some folly that had not been nourished by Jesus". The magic apology of $\mathrm{M}$. Pico's speech did not coincide with J. Colette's perception of the oneness of ancient divinity. His position is clearly reflected in the position of the typical Christian humanism.

In general, unlike the Italian Renaissance humanists, the synthetic religion founded by Northern European humanists M. Fichino and M. Pico, and the concept of its only ancient genealogy, did not have much influence because of the ideological pressure of Augustine's conclusions on hermeticism. In short, the traditions of the Northern European Renaissance were not inherent in intellectualism and ideological tolerance, which included all elements of doctrine.

\section{RESULTS \& DISCUSSIONS}

Secondly, Pico's work on the speech of the dignity of Pythagoreans is influenced by the metaphysical idea of metamorphosis and its use as an argument in proving their own ideas. M. Pico does not point out that this idea of the Pythagoreans is incompatible with Christian doctrine.

Third, both M. Pico and M. Fichino face the problem of the coherence of esoteric ideas, both written and oral, in the creation of their syncretic theological concepts. M. Pico's speech clearly illustrates this problem. "Moses wrote the law of the peoples, but his interpretation was oral only to Jesus and to his followers. As Origen said, Jesus taught his followers many lifesaving wisdom. But the followers did not want to write these stories because they did not want the secrets to be made public. This view is also confirmed by Dionysius Areopagit. "The founders of our religion have transmitted from my mind to reason, without writing its mysterious truth" [26]. Ficino also believes that Christian truths such as Hero, Orpheus, and Zoroastrianism are taught by Christian truths, such as the logos of the son-in-law of the world, as M. Pico did. [27]

L. Lactantsi, Clement Alexandrsky, and A. Augustustin seek to justify his great interest in occultism, based on his comments on the ancient nature of esoteric knowledge and the quotations from hermetic texts, although they are inconsistent. Unlike the North American humanists, Florian humanists believed that the old esoteric ideas were neither written in the Old Testament nor in the New Testament, but should be sought from other sources. "M. Pico describes Jesus only as a life-teaching leader, while the holy book is his written source, and there is nothing new in this book."Colet, who has a strong Christian faith, rejects the idea that ancient theology is better than the Bible. He believes that the ideas of Christianity and antiquity can be synthesized. He even bases his comments on the experiences of church fathers such as F. Justin, Clement, Origen, Aurelius Augustine.

The Stoics, the Neoplatonists, and the Church Fathers who have studied the Aristotelian and Platonic teachings believe that Christianity is the perfect divine philosophy that combines all the private truths. All of the fathers of this church make good use of the intellectual and moral potential of paganism, claiming that the ancient scholars are the image of science. They also argued that the study of their morals would be of great value to a Christian. J.Kolet's lectures at Oxford are based on Erasmus's humanistic Christian ideas, the central doctrine of Northern Renaissance humanism. But before learning the ideas of Erasmus, it is necessary to study the philosophy of paganism.

"It is important to look at the interconnectedness of the years without focusing on ordinary authors, and most importantly, if the ideas of the selected thinkers are ultimately inextricably linked to Christianity. It also addresses the work of a number of patriotic thinkers, such as Vasily, Augustine, Jerome, Cyprus [31]. J.Kolet and Erasmus believed that it is possible to refer to ancient theology only in the search for the earliest sources of Christianity.

Fourth, philosophical historical studies of the Renaissance state that the ideas of the Renaissance skepticism began with the Erasmus creation of Rotterdam [32]. 
Except for the influence of Pyrron, the founder of antique skepticism, or the ideas of neopirronism, Colet's creation is also reflected in Erasmus-based renessance skepticism. Accordingly, the ability of the human mind to be glorified in the polytheistic philosophical paradigm of antiquity and in the syncretic theological concepts of Fichino and Pico, influenced by it, is questioned.

Fifthly, Fichino and Pico, who have embraced the ideas of hermeticism, neglect the objective approach to history, the critical analysis of philology, and the methods of humanistic philosophical reasoning. Instead of a critical analysis of the texts of hermeticism, both thinkers directly adopted the philosophy of the late antiquity philosophers about theological theology up to the plateau and to Moses. [33] The Erasmus-based skeptical humanism tradition continued in the work of Lorenzo Valla.

The last representative of this tradition, U. Grossin is skeptical of the thesis that the Hermetic Corps belonged to the Apostle Paul's contemporaries Areopagitic Dionysius. Calling himself grammatical, Colit distinguished Ficino and Pico from his powerful rationalism, his critical and objective, and cautious approach to the study of the past.

Fichino and Pico's research on the history of magic in the past seems to be based solely on passionate expectations, blindly convincing arguments, before the historic-critical methodology of Oxford reformer J.Kolit.

Contrary to research on the philosophy of Renaissance humanism, it is worth noting that Erasmus and J.Kolit, under pressure from their ideological, or rather religious beliefs, were developed by M. Fichino and M. Pico, initiated by L. Lactanti and Cyril Alexandrsky, in the form of syncretic theology. have failed to demonstrate their great interest in the idea of coherence.

Therefore, their worldview reflects the struggles of bipartisan contradictions about the ideas of hermeticism that have emerged from medieval argumentative research.

Such two divergent approaches to the legacy of the Renaissance in the Renaissance should not be regarded as a conflict between the north and the Italian renaissance. For example, the work of the German naturalist and humanist Cornelia Agrippa (1486-1535) (De occulta philosophia, 1510) "The Secrets of Occult Philosophy" was widely distributed, contributing greatly to the development of northern renaissance culture. [34]

In this sense, it is possible to suppose that there were two versions of the Renaissance - rational and mystical occult thinking, and, accordingly, the idea of the oneness of antiquity.

The emergence of these two mutually opposing attitudes towards the philosophical legacy of the Renaissance mentality can be explained by the manifestation of the characteristics of hermeticism as a transitional paradigm at that time. Because:
1. The Renaissance period was the second stage in the formation of the ideas of hermeticism as concrete doctrine. Even in this second phase of the process of the formation of the ideas of hermeticism as a concrete doctrine, certain laws have been manifested. According to him, the ideas of hermeticism served as a paradigm of social consciousness in the transformation of the medieval philosophical thought paradigm into the paradigm of mathematical-experimental natural science of the New Age. In this sense, it is natural to accept two different approaches to the ideas of Renaissance hermeticism that reflect the Oxford humanistic tradition of Erasmus and Colit, as well as the humanistic traditions of Florence, based on Fichino and Pico views.

2. Early medieval argumentative research has shaped the dual approach to hermeticism. This trend of dual relations has given rise to the Oxford humanistic tradition based on the views of Florence and A. Augustine, which continues throughout the Renaissance. Despite the aforementioned shortcomings, the traditions of the Florentine School, whose ideological roots are based on L. Lactanti's ideas, have facilitated the transformation of the medieval philosophical paradigm into a new era of philosophical thought.

3. During the Renaissance, the ideas of hermeticism that synthesized elements of occult spheres such as Plato, neoplatonism, magic, kabbalas, became a syncretic religious-philosophical doctrine by representatives of the Florentine humanistic traditions such as $\mathrm{M}$. Fichino and $\mathrm{M}$. Pico. The natural magic element introduced by M. Fichino reinforced the connection between the ideas of hermeticism with the experimental sciences. For this reason, the authenticity of the thesis of the ancient theology of hermetic ideas was first suggested by L. Lactanti in the early Middle Ages, and in the Renaissance, by the representatives of the humanistic tradition of Florence, such as M. Fichino and M. Pico. despite the fact that he is I. Newton and F. It was instrumental in the formation of natural and scientific views of adherents of experimental sciences such as Bacon.

The natural magical element in M. Fichino and M. Pico's conceptions of theological theology provided an ideological opportunity for the recognition of material, physical or nature, and the study of what the church denounced. The principle of glorifying and dividing man in the concept of syncretic theology has, on the one hand, created a favorable ideological environment in the public consciousness for the substitution of the principle of creationism between pagan and later. This, in turn, served as an ideological basis for secularization processes. On the other hand, F. Bacon also served as an ideological motivation for the principle of the establishment of human control over nature through science. 


\section{CONCLUSIONS}

In general, research into the culture and thinking of the Renaissance period is difficult to form a holistic view of the era without referring to the phenomenon of hermeticism. This is because the idea of the Renaissance epoch reflects a process of interchange of medieval theological philosophical paradigms and experimental mathematical philosophical paradigms of the New Age. In the process of transforming the medieval philosophical paradigm into the New Age philosophical paradigm, the ideas of hermeticism served as a paradigm for the transmission of social consciousness.

The conclusions of the study can be used to improve research and methodological approaches in philosophy, social philosophy, history of philosophy, theology, psychology, sociology, history. The results can also be used in thematic events, roundtables in relevant ministries, military units and units, as well as in global and regional integration and intercultural dialogue.

\section{REFERENCES}

1. Zelinsky F. F. Hermes Three times Greatest // Onzhe. From the life of ideas: In 4 vols. St. Petersburg., 1907. Moscow: Logos, 1995 6. T. 3. P.312 P. 88-152;

2. D. Strandden, "Hermetism, its Origin, and Basic Teachings," (The Secret Philosophy of the Egyptians), 1914, edition by A. I. Voronets, St. Petersburg, 85 pp.

3. Francis A. Yates Rosencrucian education. Translation by A. Cavtaskinapod. T. Baskakova. -Moscow: Aletheia, Enigma, 1999. P. 496-476.

4. Maye J.-P. On the philosophical meaning of the "Definitions" of Hermes Trismegist // Yearbook of the Armenian Branch of the Philosophical Society of the USSR, 1985. - Yerevan, 1986. - P. 202-214 In the army. lang Res. In Russian

5. Fetugiere A.-J. Corpus Hermeticum. T. 1-4 - Paris, 19451954.

6. Scott Walter (and A. S. Ferguson). Hermetica. The Ancient Greec and Latin Writings, which Contain Religious and Philosophic Teachings Ascribed to Hermes Trismegistus. 4 vols. - Oxford, 1924-1936.

7. Panin S. Discussions on the methodology of the study of esotericism in the works of European and North American authors in the journal Religious Studies, No. 12 (9-10), p. 60-73

8. Shaburov N.V. The Perception of Hermeticism by the Ideologists of Early Christianity (Lactantius and Augustine) The Meroe Collection. Vol. 3. M., 1985. P. 243-252.

9. Kudryavtsev O.F. The "learned religion" of the Florentine Academy // Renaissance Culture and the religious life of the era. Moscow: Nauka, 1997.P. 186.P. 88-96.

10. Erasmus Desiderius. Opus epistolarumDes.ErasmiRoterodami / Rec. per P.S. et H.M. Allen, Oxford, 1906, t. I, No. 118, p. 274.

11. Colet J. Enarratio in Epistulam Primam B. Pauli ad Corinthianos. A new edition of the latin text / Trans. and introd. By B. O'Kelly and C. A. Jarrott, New York 2005, P-486. P-216.

12. Colet J. Opus de caelesti Dionysii Hierarchia. Opus de ecclesiae Dionysii Hierarchia / Ed. and trans. by J.H. Lupton, London, 1999, p. Xxv.

13. Seebohm F. The Oxford Reformers. Colet, Erasmus and T. More. LONGMANS, GREEN, AND CO. LONDON, NEW YORK, AND BOMBAY. 1896. P-548. P324.Lupton J.H. A. life of John Colet, D. D., dean of St.
Paul's and founder of St. Paul's school. With an appendix of some of his English writings. London: G. Bellandsons., 1909.P 352. Mason A.J. Lectures On Colet, Fisher, And More At St. Paul's Cathedral, 1894 .... London, NabuPress 2011.P 136.

14. Jaine S.R. John Colet and MarsilioFicino, London, Oxford University Press. 1963. P 212.P 63.

15. Yates F.A. Giordano Bruno and the Hermetic Tradition / Per.sang. G. Dashevsky, -M: New Literary Review, 2000. - 528 p. S-88. Ilya Kasavin Hermeticism, magic, natural philosophy in European culture of the 13th-19th centuries, Moscow: Canon + ROOI "Rehabilitation", 1999. - 864 p. C 253.

16. Walker D.P. Spiritual and Demonic Magic from Ficino to Campanella, The Pennsylvania State University Press, 2000. P-256. p. 1-24.Yates F.A. Giordano Bruno and the Hermetic Tradition / Per.sang. G. Dashevsky, -M: New Literary Review, 2000. - 528 p., P -24-78.

17. Pico J. Speech on the dignity of man. Per. with lat. L.M. Bragina // History of aesthetics. Monuments of world aesthetic thought, Moscow: Academy of Arts of the USSR, 1962, v. 1, C 512., P. 507-509.

18. Bragina L.M. Socio-ethical views of the Italian humanists. The second half of the XV century. Moscow: Moscow State University, 1983.- 303 p. 270.

19. Thorndike L. A History of Magic and Experimental Science, New York, Macmillan, 1923. P-892. p. 494.

20. Yates F.A. Giordano Bruno and the Hermetic Tradition / Transl. G. Dashevsky, -Moscow: New Literary Review, 2000. - 528 p. C-101.

21. Thorndike L. A History of Magic and Experimental Science, New York, Macmillan, 1923. P- 892. p. 494.

22. Clutton G. Termaximus: A Humanist Jest // Journal of the Warburg Institute, II, 1938-1939, p. 266-268.

23. Parks G.R. Pico della Mirandola in Tudor translaition // Philosophy and Humanism. Renaissans Essays in honor of P. O. Kristeller, Leiden, 1976, P. 352. P-199.

24. Colet J. Enarratio in Epistulam Primam B. Pauli ad Corinthianos. A new edition of the latin text / Trans. and introd. By B. O'Kelly and C. A. Jarrott, New York 2005, P-486. P-216.

25. Pico J. Speech on the dignity of man. Per. with lat. L.M. Bragina // History of aesthetics. Monuments of world aesthetic thought, Moscow: Academy of Arts of the USSR, 1962, v. 1, C 512. S-508-509.

26. Rebrik V.V. Hermeticism and Christianity: common ground // Measure, 1994, No. 2, p. 14.

27. Shaburov N.V. Perception of hermeticism by the ideologists of early Christianity (Lactantius and Augustine) // Meroe, vol. 3, Moscow, 1985, P. 243-252.

28. Colet J. Enarratio in Epistulam Primam B. Pauli ad Corinthianos. A new edition of the latin text / Trans. and introd. By B. O'Kelly and C. A. Jarrott, New York, 2005, P-486.p. 216-217.

29. Erasmus of Rotterdam. The weapons of a Christian warrior / Per. with lat. Yu.M. Kagan // Erasmus of Rotterdam. Philosophical works. M.Nauka, 1987 .-- 702. P-101-102.

30. Jerome. (340-420 years). The messages. Lxx. To Magnus, the great orator of the city of Rome. 397 g. 1-6. Per. with lat. under the editorship of I.P. Strelnikova. Monuments of medieval Latin literature of the 4th -9 th centuries. Moscow, 1970, pp. 45-47.

31. Popkin R.H. The history of skepticism from Erasmus to Spinoza. London University of California Press. 1953.P360.P-121. 
32. Yates F.A. Giordano Bruno and the Hermetic Tradition / Transl. G. Dashevsky, -Moscow: New Literary Review, 2000. - 528 p. S-150-158.

33. Yates F.A. Giordano Bruno and the Hermetic Tradition / Transl. G. Dashevsky, -Moscow: New Literary Review, 2000. - 528 p. S-150-158.

34. Thorndike L. A History of Magic and Experimental Science, New York, Macmillan, 1923. P- 892. p. 127. 